\title{
TRABAJOS DE INVESTIGACIÓN
}

Perales Poveda, María D., La influencia de la Masonería alicantina en la sociedad de la Restauración: 1875-1923, memoria de licenciatura leída, bajo la dirección del Prof. Dr. Rafael Zurita Aldeguer, en el Departamento de Humanidades Contemporáneas de la Universidad de Alicante el 5 de mayo de 2004.

Desde 1983, la mayor parte de los estudios realizados en España sobre masonería se llevan a cabo bajo la dirección del Centro de Estudios Históricos de la Masonería Española (CHEME) que coordina y dirige el profesor Ferrer Benimeli. Esto supone que en España resulte habitual lo que desde hacía tiempo tenía lugar en otros países como Bélgica, Italia o Francia, en los que se venían realizando estudios de carácter histórico, dedicados a la masonería y sus implicaciones sociales, ideológicas, políticas culturales... En España, desde la década de los 80, en diversas universidades se están llevando a cabo una serie de estudios, que pretenden profundizar en la composición sociológica de las logias, planteándose hipótesis de trabajo en las que se cuestiona aspectos tales como la influencia determinante de las logias en la sociedad y en la evolución política de su tiempo, la realidad de la masonería como fenómeno de la historia sociopolítica o la interacción entre sociedad y masonería.

La revolución de 1868 y los cambios políticos que llevó aparejados, supuso que la masonería española dejase de ser perseguida, lo que permitió al amparo de la nuevas Leyes de Asociación, un resurgir de la misma después de tantos años de trabas y persecución gubernamental. En el período comprendido entre 1868 y 1899, la fachada mediterránea se convirtió en una de las zonas de la península española de mayor expansión masónica, y más concretamente las comarcas valencianas del sur, con Alicante a la cabeza, experimentaron un importante proceso de auge y expansión, propiciado en buena medida, por la propaganda que supuso la elección en 1876 del jefe del partido liberal Práxedes Mateo Sagasta como Gran Maestre del Gran Oriente Español. Durante este periodo, hemos podido constatar a partir de la documentación extraída del Archivo Nacional de Salamanca que se crearon cuatro logias para la ciudad de Alicante, y once repartidas en todo el territorio de la pro- 
vincia. Además de las logias, varios organismos masónicos entre los que cabe destacar el Capítulo Lucentino y la Cámara de caballeros Kadoch.

Sigue siendo bastante común asociar a la masonería tanto a objetivos de control nacional e internacional, como al poder político y económico. Ha contribuido a ello, el llamado "secreto masónico", impulsado tanto por los enemigos de la Orden del Gran Arquitecto del Universo, como por sus miembros, lo que complica la posibilidad de conocer el influjo real que la masonería pudo ejercer en la sociedad de su tiempo.

En el caso de Alicante, hemos podido comprobar que las logias, conformadas por una mesocracia muy vinculada en lo político a las diferentes facciones del partido republicano, formaron parte de un tejido asociativo que en la segunda mitad del siglo XIX, se mantendría como un plano intermedio entre los individuos y sus relaciones personales y entre el Estado y sus instituciones, desempeñando un doble papel: como apoyo y protección al individuo y a la vez como instrumento de control de las respuestas y comportamientos contrarios a los intereses y estabilidad del sistema que pudiera generar determinados sectores de la sociedad. Hemos de considerar al respecto, que la masonería decimonónica, lejos de asumir el papel "revolucionario" y de subversión del orden que tradicionalmente se le ha venido adjudicando, hará eco de propuestas abocadas a la creación de un modelo de Estado organicista, que trate de armonizar la acción individual, la social y la del Estado, teniendo siempre como referencia un orden de valores en el que, la liber- tad, la preponderancia del individuo, la búsqueda del conocimiento y el valor de lo universal habrán de ser la piedra angular. Para ello, se dedicaron algunas tenidas a fomentar el sentido crítico de sus asistentes, buscando consolidar la conciencia democrática de sus adeptos. Con esta mentalidad, los masones alicantinos pusieron en marcha campañas contra la pena de muerte, la esclavitud, y la prostitución reglamentada. De igual modo, las logias femeninas -en el caso de Alicante la Cámara de Adopción creada por la Constante Alona- sirvieron para que un número considerable de mujeres de clase media, unidas por su heterodoxia, hiciesen causa común en la defensa de la libertad, del progreso y de la razón.

La fe en la educación como motor de cambio en la sociedad respondía a una idea generalizada de los liberales de la época y será precisamente en las reformas pedagógicas y en la defensa de un sistema educativo ajeno a los presupuestos de toda religión, donde mayormente influirían los núcleos intelectuales. En Alicante, las logias y los círculos de libre pensamiento, haciendo causa común, no solo pusieron en marcha numerosas campañas en pro de la enseñanza laica y de la educación femenina, sino que además, crearon cuatro escuelas laicas, y una escuela destinada a instruir a las clases trabajadora que estuvo vinculada exclusivamente a la logia Constante Alona.

La participación de la masonería en la realidad de su tiempo estuvo además marcada por una individualización del masón que, instalándose en las propias estructuras del sistema, interferirá en muchos casos en actitudes 
y en ideas abocadas al bien general. En la esfera de lo económico, dos instituciones claves para la modernización económica de nuestra ciudad - La Caja Especial de Ahorros y la Cámara de Comercio- fueron proyectos promovidos e impulsados por Eleuterio Maisonnave, iniciado en 1876 en la logia Constante Alona con el nombre simbólico de "Pericles», además los Consejos de Administración de ambas instituciones a su creación, contaron con la presencia de hombres de élite en la vida masónica alicantina: Amando Alberola, Manuel Ausó Monzó y Ausó Arenas, Primitivo Carreras, José Guardiola, Francisco Linares Such y José Gacia Soler entre otros.

De igual modo, el Ayuntamiento de Alicante entre 1887 y 1895 contaría con la presencia de varios masones alicantinos, periodo coincidente con el inicio de remodelación urbanística, que si bien en Alicante estuvo siempre a remolque de los intereses de la burguesía local, la conciencia crítica de urbanistas y pensadores se enfrentó a la incapacidad de ciertas sociedades para modernizar la ciudad en base a los nuevos criterios higienistas que nos iban llegando de Euro- pa. Además, la creación de un nuevo cementerio con un espacio destinado al enterramiento civil y la puesta en práctica de medidas higiénico-sanitarias para el mantenimiento de la salubridad pública daban muestras de interés por dotar a la ciudad de una amplia oferte de servicios $\mathrm{e}$ infraestructura, a pesar de las limitaciones propias de los Ayuntamientos restauracionistas.

Los miembros de la Orden, hicieron notar además su presencia en buen número de sociedades de acometido cultural: El Ateneo de Alicante, la Sociedad de Escritores y Artistas, la Sociedad Iris o la Sociedad económica de Amigos del país y ocuparon cargos de dirección y de fundación en la mayor parte de periódicos alicantinos de ideología progresista: Las Germanias, La Unión Democrática, El Liberal, El Porvenir, El Republicano, El Crisol...

En esencia, sin querer adjudicar a la masonería un protagonismo que no tuvo, hemos de admitir que su actividad se tradujo en un impulso de apertura intelectual frente al ostracismo imperante que iría progresivamente cristalizando en un cambio de mentalidad de los ciudadanos alicantinos. 